\title{
Biostratigraphic precision of the Cruziana rugosa group: a study from the Ordovician succession of southern and central Bolivia
}

\author{
SVEN O. EGENHOFF*, BERND WEBER $\dagger$, OLIVER LEHNERT $\ddagger \&$ JÖRG MALETZ $\S$ \\ ${ }^{*}$ Colorado State University, Department of Geosciences, 322 Natural Resources Building, Fort Collins, \\ CO 80523-1482, USA \\ $\dagger$ Freie Universität Berlin, Institut für Geologische Wissenschaften, Fachrichtung Geologie, \\ Malteserstrasse 74-100, D-12249 Berlin, Germany \\ $\ddagger$ University of Erlangen, Institute of Geology and Mineralogie, Schlossgarten 5, D-91054 Erlangen, Germany \\ §Department of Geology, State University of New York at Buffalo, 772 Natural Sciences \\ and Mathematics Complex, Buffalo, New York 14260-3050, USA
}

(Received 10 October 2005; revised version received 1 May 2006; accepted 22 May 2006)

\begin{abstract}
Cruziana ichnospecies have been repeatedly reported to have biostratigraphic significance. This study presents a re-evaluation of the arthropod ichnotaxa of the Cruziana rugosa Group from bio- and/or lithostratigraphically well-defined Lower to Upper Ordovician siliciclastic sections of southern and central Bolivia. With the exception of Cruziana rouaulti, the ichnofaunas contain all the members of the Cruziana rugosa Group throughout the Ordovician (Arenig to Caradoc) successions in Bolivia. The Bolivian material therefore indicates that these arthropod ichnofossil assemblages are suitable for recognizing Ordovician strata in Bolivia. These findings cast doubt on their use as reliable indicators for a global intra-Ordovician (Arenig to Caradoc) biozonation of Peri-Gondwanan sedimentary successions.
\end{abstract}

Keywords: Cruziana, biostratigraphy, Bolivia, Ordovician.

\section{Introduction}

The ichnotaxon Cruziana is one of the best-known arthropod ichnogenera used for facies analysis (Frey \& Pemberton, 1984; Pemberton et al. 1992), but its biostratigraphic relevance is even more important because it enables dating of sandstone units lacking body fossils (Crimes, 1968, 1969; Seilacher, 1970, 1992, 1994). This approach has also served to subdivide Silurian oil-bearing units in Libya (Seilacher, 1992). Although some studies cast doubt on the biostratigraphic relevance of certain Cruziana ichnospecies (Magwood \& Pemberton, 1990), the lack of indicative fossils accompanying Cruziana has prevented an independent control to date.

One of the most abundant Cruziana ichnoassemblages in the world is the 'Cruziana rugosa Group'. It consists of the four members of Cruziana furcifera, Cruziana goldfussi, Cruziana rouaulti and Cruziana rugosa. Two members of this ichnoassemblage, Cruziana furcifera and Cruziana rugosa, were first described from the Ordovician successions of Bolivia (d'Orbigny, 1839, 1842). Stratigraphically, the 'Cruziana rugosa Group' is restricted to Lower Ordovician strata according to Seilacher (1970, 1992), keeping in mind that Seilacher (1970, 1992) only subdivides the Ordovician into Lower and Upper without a Middle Ordovician interval, in contrast

*Author for correspondence: sven@warnercnr.colostate.edu to the present study. However, Bolivia is the only place worldwide where Seilacher (1992) reports that the occurrence of the 'Cruziana rugosa Group' continues stratigraphically into the Upper Ordovician. Although Seilacher reassigned these Caradocian quartzites in Bolivia to the Middle Ordovician in a personal communication in Mángano \& Buatois, 2003, the thick quartzitic units near Cochabamba are at least partly Caradoc in age (Gagnier et al. 1996). If this were true, Bolivia would offer the unique possibility to find out about the real stratigraphic range of the 'Cruziana rugosa Group'. However, the presence of this ichnoassemblage in Upper Ordovician rocks as reported by Seilacher (1992) was not sustained by any independent biostratigraphic data. The present contribution therefore aims at dating these Upper Ordovician Cruziana occurrences with new fossil findings. Furthermore, in a later paper, Seilacher (1994, p. 754, fig. 2) returned to his earlier view with Cruziana rugosa being indicative only for the Lower Ordovician and did not discuss his own observations from Bolivia. The exact stratigraphic range of the 'Cruziana rugosa Group' therefore remains unclear to date.

The aim of this paper is to describe and taxonomically define all four members of the C. rugosa Group, based on well-preserved and hitherto undescribed trace fossil material from four localities in central and southern Bolivia. The excellent preservation of the trace fossils enables a discussion on the validity of Seilacher's (1970) original ichnospecies 
differentiation. In contrast to most of the published Cruziana-bearing successions, the herein-presented specimens of $C$. furcifera, $C$. goldfussi, C. rouaulti and $C$. rugosa occur in successions where the biostratigraphy is well known based on indicative body fossils and/or the lithostratigraphic position allows the definition of the age of the investigated specimens. Based on these data it is possible to test the biostratigraphic validity of the Cruziana rugosa Group for Bolivia and discuss its use for Peri-Gondwanan successions worldwide.

\section{Geological setting}

Shallow marine siliciclastic deposits are common in the Ordovician successions of Andean Bolivia (Suarez Soruco, 1976). They were deposited on the lowinclined eastern flank of a basin delimiting the Brazilian Shield in the west (Gohrbandt, 1992). Nowadays, these siliciclastic deposits form a major part of the Eastern Cordillera in NW Argentina, Bolivia and southern Peru. The sediments show a cumulative thickness of more than $15 \mathrm{~km}$ and can be regarded as the most prominent Ordovician succession worldwide (Egenhoff, 2000).

The age of the shallow-marine siliciclastic deposits in the Eastern Cordillera of southern to central Bolivia decreases from south to north (Suarez Soruco, 1976). In the Tarija region (Fig. 1), the clastic deposits are of early Tremadoc to Arenig age. Around Potosí and Sucre, Middle and some Upper Ordovician sediments are exposed, whereas near Cochabamba, sediments of Caradoc and Ashgill age (Upper Ordovician) predominate (Suarez Soruco, 1976). Unfortunately, neither the litho- nor the biostratigraphy is well established, except for the Tarija area (Rivas, Fernandez \& Alvaro, 1969; Erdtmann et al. 1995; Maletz \& Egenhoff, 2001). All presumably lower Llanvirn (Middle Ordovician) sediments around Potosí and Sucre are grouped into the Capinota Formation, and every lithostratigraphic unit of supposed upper Llanvirn and Caradoc age is referred to as the Anzaldo Formation (Fig. 2) (Rivas, 1971; Suarez Soruco, 2000). The top of the Ordovician succession is marked by the non-fossiliferous sandstonedominated San Benito Formation of assumed Ashgill age. Its prograding geometries are interpreted to reflect the sea-level fall in the late Ashgill due to the onset of the Hirnantian glaciation (Sempere, 1995).

\section{The Bolivian material of the Cruziana rugosa Group}

In the Bolivian Ordovician, all four species of the 'Cruziana rugosa Group' (Seilacher, 1970) occur and are described in detail below. Several specimens of C. rugosa, C. furcifera, C. rouaulti and C. goldfussi have been collected in the localities of Sella, Cienega, Tipa Jara and Liriuni (Fig. 1). Liriuni, in the vicinity

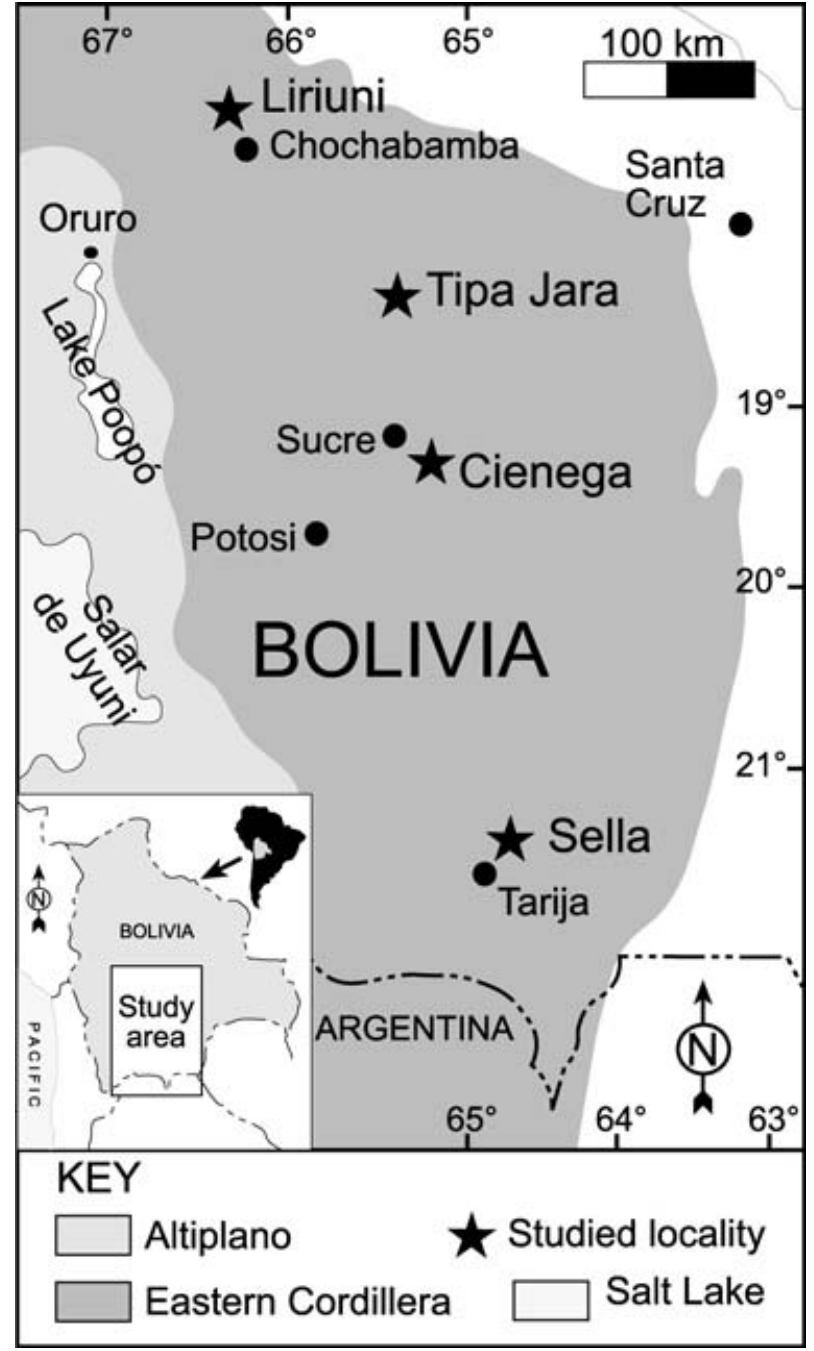

Figure 1. Location of the study area in central and southern Bolivia. The four investigated localities are marked with black stars.

of Cochabama, is incorporated in this study because it represents the type locality of C. rugosa and C. furcifera (d'Orbigny, 1839, 1842).

With exception of the specimens in Figure $5 \mathrm{a}$ and $\mathrm{b}$ which are property of the Museo 'Alcide d'Orbigny', Cochabamba (Bolivia), all specimens are stored in the collections of the Freie Universität Berlin, Institut für Geologische Wissenschaften, Fachrichtung Geologie, Berlin-Lankwitz (Germany).

\section{3.a. Description of the members of the $C$. rugosa Group}

\section{Ichnogenus Cruziana d'Orbigny 1842 Cruziana rugosa d'Orbigny 1842}

Figure $3 \mathrm{a}-\mathrm{c}$

Material. Thirty-five specimens from three localities, some well preserved, mainly as positive hyporeliefs in yellow-reddish or light brown massive and finegrained (to silty) sandstones from the Chaupi Cancha creek and from a neighbouring locality near the old 

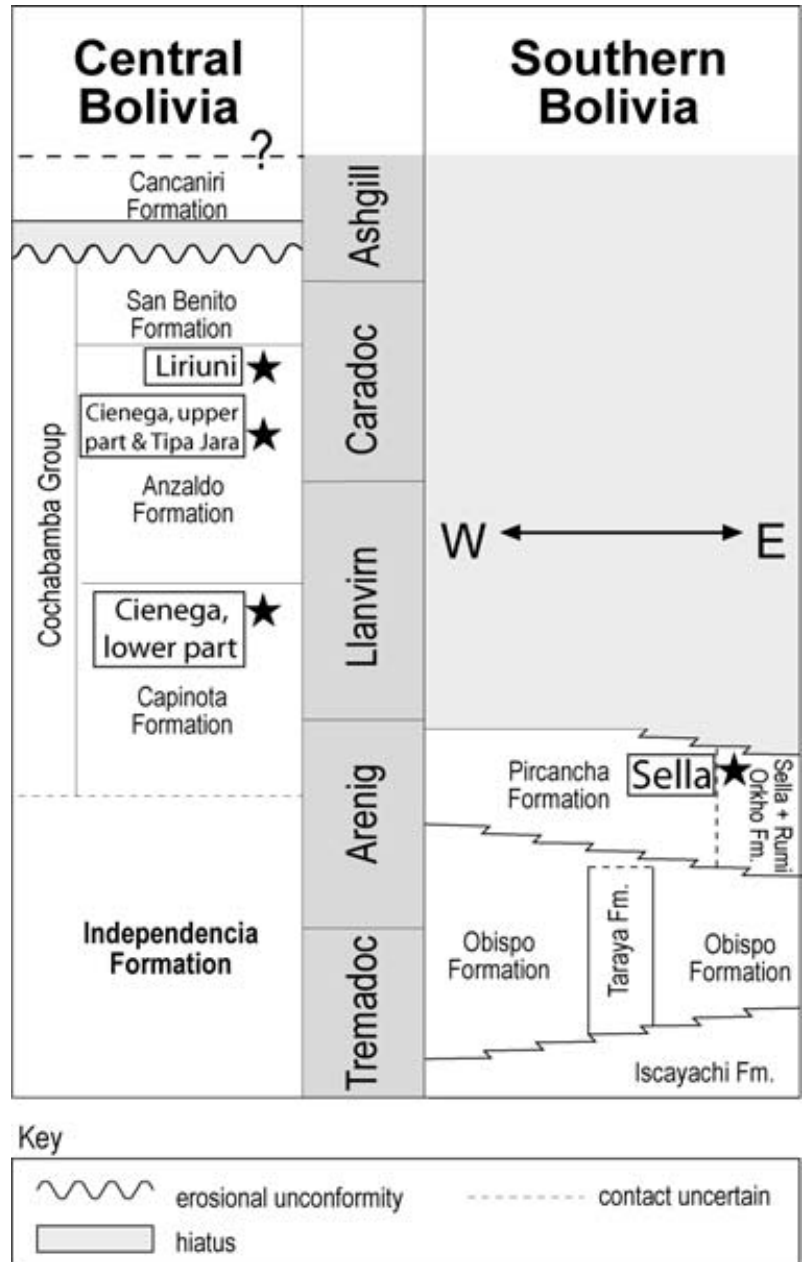

Figure 2. Stratigraphic overview scheme for the Ordovician succession in central (left) and southern (right) Bolivia. Note that in the study area of southern Bolivia only Lower Ordovician rocks are exposed, whereas in central Bolivia, Middle and Upper Ordovician strata also crop out. The biostratigraphy of the southern Bolivian units is much better constrained than in central Bolivia due to the higher abundance of indicative fossils in the south. The black stars indicate the approximate stratigraphic position of the four investigated localities. Data compiled from Egenhoff (2000), C. Hildebrandt (unpub. Diploma thesis, Univ. Freiberg, 2003), Rivas, Fernandez \& Alvaro (1969) and Suarez Soruco (2000).

cemetery of the village of Sella, north of Tarija, SE Bolivia (Fig. 1). Cruziana rugosa is in general the most common ichnospecies in the Rumi Orkho Formation in Sella (Fig. 3a). Further measured, and in part photographed, material remains in situ in the field, particularly some big slabs in natural position in the outcrop Chaupi Cancha near Sella. One further wellpreserved specimen (Fig. 3b) has been collected from a Middle to Upper Ordovician locality near Tipa Jara (Aiquile, SE Cochabamba province). Cruziana rugosa also occurs in the Liriuni section (Caradoc).

Description. Mostly deep and relatively short bilobate trace fossils showing a pronounced median furrow and steep vertical declining margins. Size usually varying in a relatively small range of about 50 to $90 \mathrm{~mm}$ in width (each lobe $\sim 20-30 \mathrm{~mm}$ wide). D'Orbigny (1842) measured a width of $85 \mathrm{~mm}$ for the type species. Only in a few cases, the traces may be smaller $(\sim 12$ $20 \mathrm{~mm}$ in width). Length relatively short $(\sim 100$ $200 \mathrm{~mm}$ long; after d'Orbigny, 1842, $150 \mathrm{~mm}$ ), straight and vertically curved digging traces resulting in the typical domed casts preserved in positive hyporelief.

The surface of both lobes shows the impressions of the endopod grouped in sets of 5 to 12 individual impressions running parallel or in varying V-angles (up to about $90^{\circ}$ ), that is, transverse to the trace axis/median furrow. The orientation of the scratch marks (endopod impressions) indicates a procline ploughing of the trace originator through the sediment. C. rugosa is characterized by coarse transverse ridges (or bundles) about 5 to $15 \mathrm{~mm}$ wide superimposing the digit impressions (single scratches) and are arranged in opposite pairs at an angle of about $90^{\circ}$ to the median furrow.

\section{Cruziana furcifera d'Orbigny 1842}

Figures 3d, e, 4a, b

Material. Thirteen specimens from all four localities, preserved in positive hyporelief in a massive yellowishbrown silty sandstone from the Sella locality (Fig. 3d). In addition to the collected material (Figs 3e, 4a, b), other non-collectable specimens from the Middle to Upper Ordovician localities of Cienega and Tipa Jara have been examined in the field.

Description. Relatively large ( $\sim 20-100 \mathrm{~mm}$ wide and up to some decimetres long) bilobate trace fossils in the form of usually straight and relatively flat-domed moulds (casts in positive hyporelief preservations). Median furrow pronounced, lobe margins, in contrast to C. rugosa, gently and smoothly downsloping to the median furrow as well as to the lateral trace margins. The lobes show rhythmically and periodically occurring flat swellings running transversally to the median line, causing an undulation of the primary straight scratches. The orientation of the scratches indicates an opisthocline ploughing of the trace originator through the sediment. They are in V-shaped orientation, mostly with acute angle in relation to the trace axis, in some cases showing also nearly longitudinal (parallel) position to the trace axis and usually superimposing each other, which results in the characteristic reticulate patterns on the surface of the lobes.

Remarks. Cruziana furcifera was interpreted to represent merely a variant of $C$. rugosa and C. goldfussi, respectively, reflecting different behaviour modes or preservational aspects (Kolb \& Wolf, 1979). However, the lack of the transverse bundles and the flat-dipping lateral trace margins without any signs of genal spine grooves, especially in well-preserved specimens 

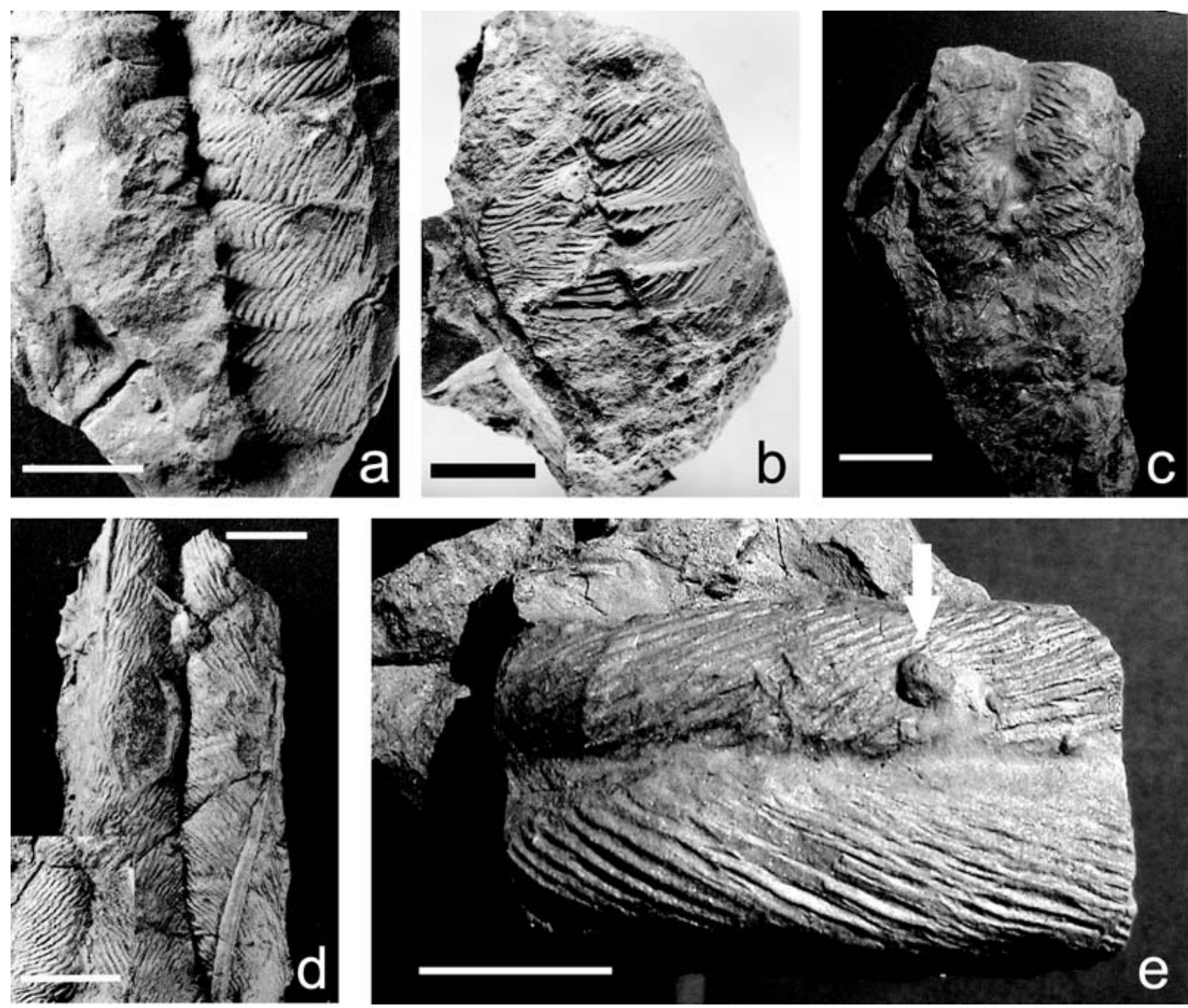

Figure 3. (a) Cruziana rugosa d'Orbigny 1842. Well preserved specimen showing the typical bundle-shaped ornamentation of the endopodal lobes in Cruziana rugosa. Specimen SE-98-31; Arenig, Rumi Orkho Formation, Sella near Tarija (southern Bolivia); (b) Cruziana rugosa d'Orbigny 1842, from the Tipa Jara locality demonstrating the typical steeply domed lobes with the prominent scratch mark pattern, superimposed by bundle-shaped wrinkles on the lobe surface. Specimen Ai-01-52, Middle (?) to Upper Ordovician, Anzaldo Formation; (c) Cruziana rugosa d'Orbigny 1842. Poorly preserved but significant specimen with typical bundle-shaped wrinkles superimposing scratch mark patterns on the lobe surfaces. Specimen Lir-01-II, upper Anzaldo Formation (Caradoc), Liriuni locality (Central Bolivia); (d) Cruziana furcifera d'Orbigny 1842. Two examples of this ichnogenus showing the flat to slightly domed endopodal lobes with a (C. goldfussi-like) scratch mark ornamentation but without lateral genal spine grooves. The specimen SE98-24 (big photo) is partly crossed by a hyporelief of Palaeophycus isp. The magnification in the inset photo (specimen SE-98-37) demonstrates the typical reticulate shape of the scratch mark pattern on the lobes. Arenig, Rumi Orkho Formation, Sella; (e) Cruziana furcifera d'Orbigny 1842. Well preserved specimen showing the flat to slightly domed endopodal lobes with the reticulate scratch mark pattern. The Cruziana trace is cut by a vertical (non-arthropod) trace of the Skolithos type (arrow). Specimen CC-01-04, Anzaldo Formation, Cienega. Scale bar equals $2 \mathrm{~cm}$ in each of the photos.

which are frequently accompanied by well-preserved specimens of C. rugosa and C. goldfussi in the same layer, demonstrate the ichnotaxonomically distinctive characteristics of $C$. furcifera.

Cruziana goldfussi Rouault 1850 (Lebesconte, 1883)

Figures $4 \mathrm{c}-\mathrm{e}, 5 \mathrm{a}, \mathrm{b}$

Material. One specimen (SE-98-30: Fig. 4c) well preserved as positive hypo-relief in yellowish-brown silty sandstone from the Arenig of the Rumi Orkho Formation of Chaupi Cancha near Sella (leg.: P. Diaz, Tarija). A further two specimens from the Middle to Upper Ordovician succession of Cienega and Tipa Jara, central Bolivia, could not be collected (Fig. 4d, e) because they formed part of a large boulder. Two other specimens from the Liriuni locality (Caradoc) are stored in the collection of the Museo 'Alcide d'Orbigny' in Cochabamba (Fig. 5a, b). 

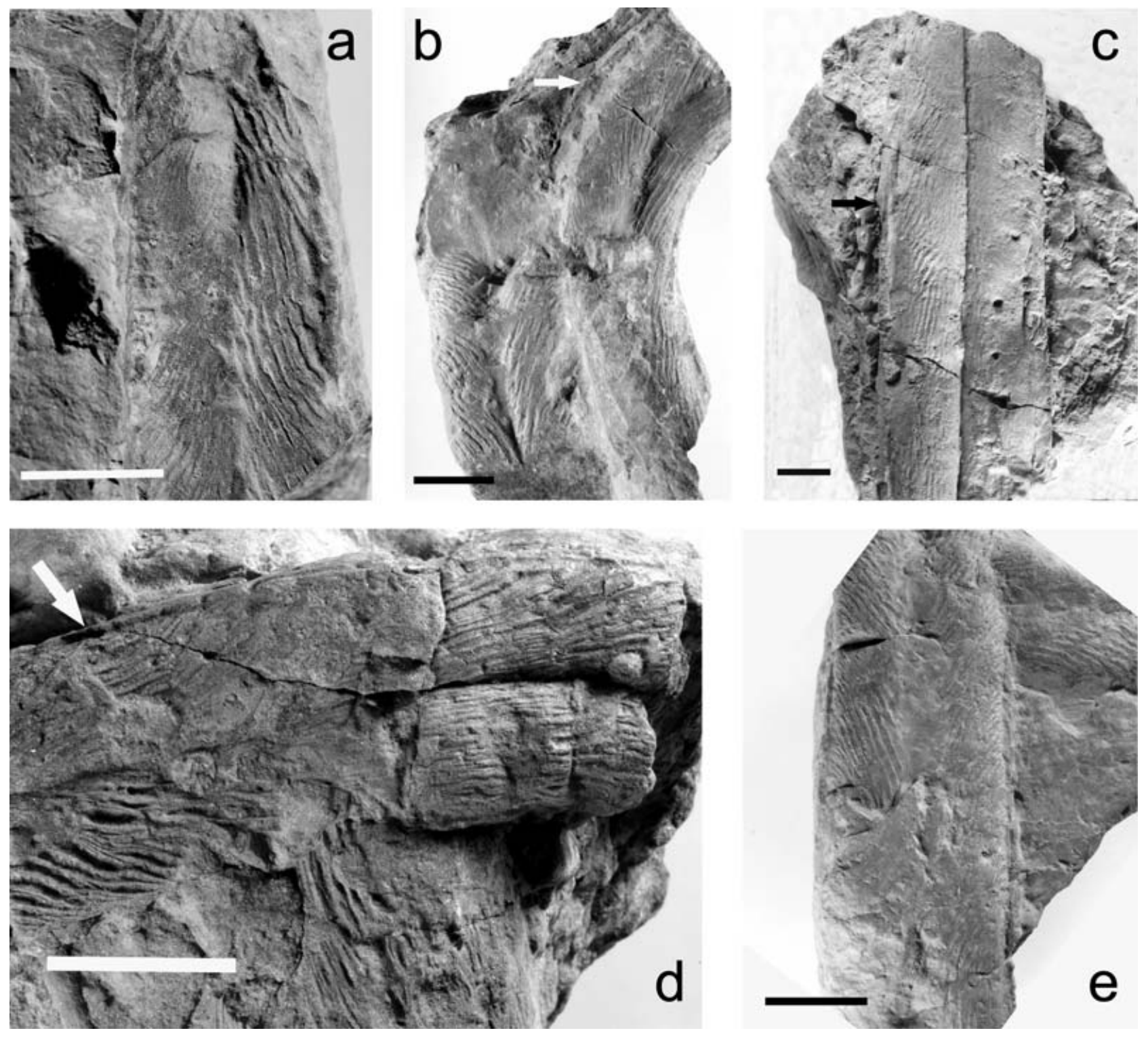

Figure 4. (a) Cruziana cf. furcifera. A poorly preserved Cruziana furcifera. The lateral structure on the left-hand lobe edge could also represent a remnant of a genal spine groove and therefore this specimen might be interpreted as a 'transition' to C. goldfussi only due to preservational aspects. Specimen Ai-01-50, Middle (?) to Upper Ordovician, upper Anzaldo Formation, Tipa Jara; (b) Cruziana furcifera d'Orbigny 1842 and Cruziana goldfussi Rouault 1850 (Lebesconte, 1883). Specimen from Tipa Jara with Cruziana furcifera (left) and Cruziana goldfussi showing the characteristic genal spine groove preserved as lateral ridge (arrow). Specimen Ai-01-51, Middle (?) to Upper Ordovician, upper Anzaldo Formation, Tipa Jara; (c) Cruziana goldfussi Rouault 1850 (Lebesconte, 1883). Specimen showing the flat endopodal lobes and the typical lateral genal spine grooves (arrow) in Cruziana goldfussi. Specimen SE-98-30; Arenig, Rumi Orkho Formation, Sella; (d) Cruziana goldfussi Rouault 1850 (Lebesconte, 1883). Specimen showing the typical flat lobes with the remains of a genal spine groove preserved along the upper lobe (arrow). Specimen CC-01-15, Anzaldo Formation, Cienega; (e) Cruziana goldfussi Rouault 1850 (Lebesconte, 1883). Well preserved specimen of C. goldfussi showing the flat lobes laterally accompanied by the typical ridges (genal spine grooves) in positive hyporelief preservation. Specimen Ai-01-53, Middle (?) to Upper Ordovician, Anzaldo Formation, Tipa Jara. Scale bar equals $2 \mathrm{~cm}$ in each of the photos.

Description. Large and straight-running bilobate trace fossils about 60 to $70 \mathrm{~mm}$ in total width. Both endopodal lobes slightly domed, rather flat but separated by a pronounced median furrow. The orientation of the scratch marks (endopod impressions) indicates an opisthocline ploughing of the trace originator through the sediment as well as slight undulation and reticulate patterns caused by criss-crossing and superimposing of the endopodal markings. Generally, this trace type is very similar to $C$. furcifera but always with distinct lateral furrows (ridges in positive hyporeliefs, each $\sim 5-6 \mathrm{~mm}$ wide) running along the trace margins. These lateral grooves or ridges have been interpreted as possible genal (and/or pygidial) spine grooves or traces of the carapace margin dragging on the substrate (Birkenmajer \& Bruton, 1971). 

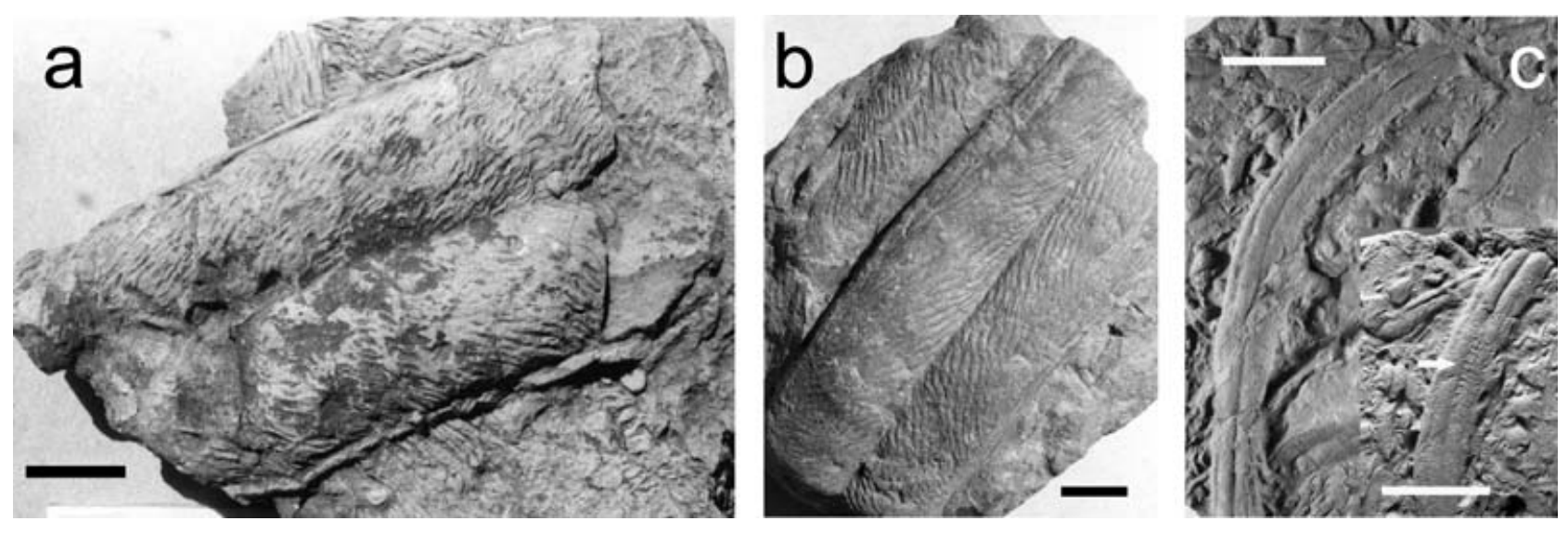

Figure 5. (a) Cruziana goldfussi Rouault 1850 (Lebesconte, 1883). Excellently preserved specimen of C. goldfussi showing the typical large and very flat lobes with the lateral ridges (genal spine grooves). Specimen: Museo 'Alcide d'Orbigny', Cochabamba (Bolivia); upper Anzaldo Formation (Caradoc), Liriuni locality; (b) Cruziana goldfussi Rouault 1850 (Lebesconte, 1883). Well-preserved specimen from the same locality as (a), demonstrating the characteristics of $C$. goldfussi. Museo 'Alcide d'Orbigny', Cochabamba (Bolivia), upper Anzaldo Formation (Caradoc), Liriuni locality; (c) Cruziana rouaulti Lebesconte 1883. Unicate slab from the Sella locality with numerous non-arthropod traces and arthropod scratch marks (e.g. Monomorphichnus isp.) and a well-preserved positive hyporelief of Cruziana rouaulti. The specimen demonstrates the typical flat and usually unornamented endopodal lobes with lateral genal spine grooves (arrow) of Cruziana rouaulti. The inset photo shows the middle part of the same specimen under another illumination angle to demonstrate the faintly preserved scratch marks close to the median furrow (arrow). Specimen SE-98-32; Arenig, Rumi Orkho Formation, Sella. Scale bar equals $2 \mathrm{~cm}$ in each of the photos.

Remarks. As the majority of ichnotaxobases of C. goldfussi are quite similar to those of C. furcifera, except in terms of the pleural furrows (genal spine grooves), C. goldfussi should be strictly used only for those specimens that clearly show these characteristic lateral furrows (ridges) coinciding with a C. furciferalike lobe ornamentation (see also emended diagnosis by Baldwin, 1977). Similar genal spine grooves are known only from the much smaller and almost unornamented $C$. rouaulti (see description below), and from C. semiplicata Salter 1853, which, however, shows another characteristic pattern of endopodite and lateral exopodite scratches on the lobes (see Seilacher, 1960; Seilacher \& Crimes, 1969; Mángano, Buatois \& Aceñolaza, 1996). Moreover, C. semiplicata seems to be exclusively restricted to the Upper Cambrian.

\section{Cruziana rouaulti Lebesconte 1883}

Figure $5 c$

Material. One excellently preserved specimen in a greyish-brown massive and fine-grained to silty sandstone from the area around Sella (Locality: Cerro de la Santa Cruz Loma, Sella Formation; specimen SE-9832; Fig. 5c).

Description. Bilobate trace fossil that consist of two narrow endopodal lobes. Traces straight or gently curved and up to some decimetres in length, with pronounced median furrow, in well-preserved specimens also showing narrow lateral furrows (ridges, each $\leq 1 \mathrm{~mm}$ wide) along the trace margins (trace of genal spines?). Endopodal lobes are generally smooth, without prominent endopodal scratches. Only excep- tionally well-preserved specimens show faint and thin transversally running ridges that have mostly a rightangled $\left(\sim 90^{\circ}\right)$ orientation to the trace axis. Endopodal lobes are each about 5-7 $\mathrm{mm}$ wide (total trace width $\sim 10-15 \mathrm{~mm}$ ). The lobes are flat (about 2-4 mm high), resulting in a characteristic flat rectangular-appearing cross-section of the traces.

Remarks. The ichnotaxonomy of C. rouaulti is not well founded and is an ongoing matter of discussion. Their similarity to other ichnogenera (e.g. Didymaulichnus, Rouaultia) has been repeatedly discussed and has resulted in contradictory synonymies (e.g. Péneau, 1946; Crimes, 1970; Young, 1972; Durand, 1985).

\section{3.b. Is a clear taxonomic differentiation of four ichnospecies of the Cruziana rugosa Group possible?}

The taxonomic criteria for the separation of the different ichnospecies of Cruziana remain critical. Seilacher (1992) distinguished 34 ichnospecies of Cruziana from the Lower Cambrian to the Lower Carboniferous of Gondwana, mainly by their different scratch patterns. Within the $C$. rugosa Group, C. furcifera is said to be the least distinctive, with the widest palaeogeographic distribution (Seilacher, 1970). However, according to Seilacher (1992), the differentiation of the four C. rugosa Group ichnotaxa is often problematic and even Seilacher (1992) states that distinguishing them can sometimes be regarded a 'matter of opinion'.

Our material from Bolivia, however, allows a clear distinction between individual C. rugosa Group 
ichnospecies. Two main characteristic and distinctive elements, the lateral (genal spine) furrow or ridge in $C$. goldfussi and the steep vertically declining margin exclusive of C. rugosa were excluded in Kolb \& Wolf's (1979) study. In no case in our collected material from Bolivia, nor in the numerous specimens observed in the field, was the typical steep C. rugosa margin found together with a lateral spine groove. The few cases of C. rugosa with supposedly lateral grooves cited by Kolb \& Wolf (1979) from the literature (Crimes \& Marcos, 1976; Bergström, 1976) seem to be misinterpretations; following the diagnosis of Seilacher (1970), the specimen figured in Crimes \& Marcos (1976, pl. 2, fig. a) is not a C. rugosa as it lacks the typical bundle-like ornamentation and shows a genal spine groove which is clearly not significant for C. rugosa. The specimen in Bergström (1976, fig. 6A) is a poorly preserved and therefore rather problematic specimen of the (?) C. rugosa type showing remains of a lateral spine groove, but not the typical bundle-shaped ornamentation of C. rugosa on the lobe surfaces, and it therefore represents rather a Cruziana aff. goldfussi. Bergström (1976, fig. 6D) illustrates a putative C. rugosa, but due to clearly visible lateral spine grooves, it is obviously a poorly preserved C. goldfussi. C. rouaulti, which also possesses lateral ridges, differs clearly from $C$. goldfussi by its much smaller and very flat lobes lacking the characteristic reticulate scratch patterns. The exclusively Cambrian ichnotaxon C. semiplicata, which is also characterized by genal spine grooves, displays a more complex lobe ornamentation consisting of very characteristic endoand exopodal scratches (Seilacher, 1990). Therefore only a taxonomic uncertainty exists in terms of the somewhat transitional characteristics of $C$. furcifera and poorly preserved $C$. goldfussi specimens lacking preservation of their lateral spine grooves. Also, Mángano, Buatois \& Moya (2001) describe C. furcifera that rarely grades laterally into $C$. goldfussi. Their figure $3 \mathrm{a}$, however, only documents an intergradation of these two well-distinguishable ichnotaxa similar to our Bolivian material. It therefore remains unclear whether the transition of one Cruziana ichnotaxon into the other as mentioned by Mángano, Buatois \& Moya (2001) is partly due to preservational aspects of the Argentinian material, or if it really represents an intergradation of two ichnospecies. But even though a transition should exist between C. furcifera and C. goldfussi, intermediate specimens are the exception rather than the norm and should not lead to the abandonment of the ichnospecies concept for the Cruziana rugosa Group (Pickerill, Romano \& Meléndez, 1984). It is concluded that the ichnotaxonomic characteristics allow a clear distinction between the four members of the C. rugosa Group in well-preserved material, and therefore, based on the excellently preserved Bolivian Cruziana specimens, Seilacher's (1970) ichnospecies are here considered valid.
Table 1. Stratigraphic occurrence of Cruziana and associated trace fossils in Bolivia

\begin{tabular}{lll}
\hline Locality & \multicolumn{1}{c}{ Stratigraphy } & \multicolumn{1}{c}{ Trace fossils } \\
\hline Liriuni & Upper Anzaldo Formation & Cruziana rugosa \\
& Upper Ordovician & Cruziana furcifera \\
& (Caradoc) & $\begin{array}{l}\text { Cruziana goldfussi } \\
\text { Palaeophycus isp. }\end{array}$ \\
Tipa Jara & Anzaldo Formation & Cruziana rugosa \\
& Middle(?) to Upper & Cruziana cf. furcifera \\
& Ordovician (Caradoc) & Cruziana goldfussi \\
Cienega & Upper Capinota and & Cruziana furcifera \\
& Anzaldo formations & Cruziana goldfussi \\
& Middle to Upper Ordovician & Palaeophycus isp. \\
& (Darriwilian to Caradoc) & Skolithos isp. \\
Sella & Rumi Orkho Formation & Cruziana rugosa \\
& Lower Ordovician & Cruziana furcifera \\
& (Arenig) & Cruziana goldfussi \\
& & $\begin{array}{l}\text { Palaeophycus isp. } \\
\text { (?)Rusophycus isp. }\end{array}$ \\
& & Monomorphichnus isp.
\end{tabular}

\section{The bio- and lithostratigraphic position of the Bolivian Cruziana ichnoassemblages}

The four localities where the Bolivian members of the C. rugosa Group have been collected correspond to differing litho- and/or biostratigraphic levels within the Ordovician succession. Each of the localities is discussed in detail below. Furthermore, a list of the trace fossil assemblage is provided for each of the investigated sections (Table 1).

\section{4.a. Sella $\left(21^{\circ} 22^{\prime} 30^{\prime \prime} \mathrm{S}, 64^{\circ} 41^{\prime} 49^{\prime \prime} \mathrm{W}\right)$}

The Lower Ordovician Rumi Orkho Formation (Fig. 2; Egenhoff, 2000; F. Schönian, unpub. Diploma thesis, Humboldt Univ., 2000), exposed near the village of Sella, about $30 \mathrm{~km}$ north of Tarija, yielded the majority of the trace fossils described in this paper. Along with several non-arthropod traces, mainly Palaeophycus isp. (see specimen in Fig. 3d), and non-specific arthropod scratch marks, the Rumi Orkho ichnofossil assemblage contains common C. rugosa, less abundant $C$. furcifera, and rare C. goldfussi and C. rouaulti (Figs 3a, d, 4c, 5c).

In the Rumi Orkho Formation, the Cruziana ichnofossils occur in interbedded sand-, silt- and mudstones. The succession is dominated by sandstones; the pelitic intercalations are relatively thin and contain a large amount of silt.

A number of relatively well-preserved graptolites were found in the Rumi Orkho Formation at Sella (Fig. 6). The graptolites are flattened and generally do not show internal structural details. However, a determination is still possible from this only slightly tectonized material. Maletz, Kley \& Reinhardt (1995) illustrated specimens of Baltograptus sp. cf. B. deflexus, while Egenhoff (2000) referred material to Baltograptus sp. cf. B. deflexus and Baltograptus minutus. The presence of these graptolites helps to delimit the age of the Rumi Orkho Formation. Maletz \& Egenhoff (2003) 


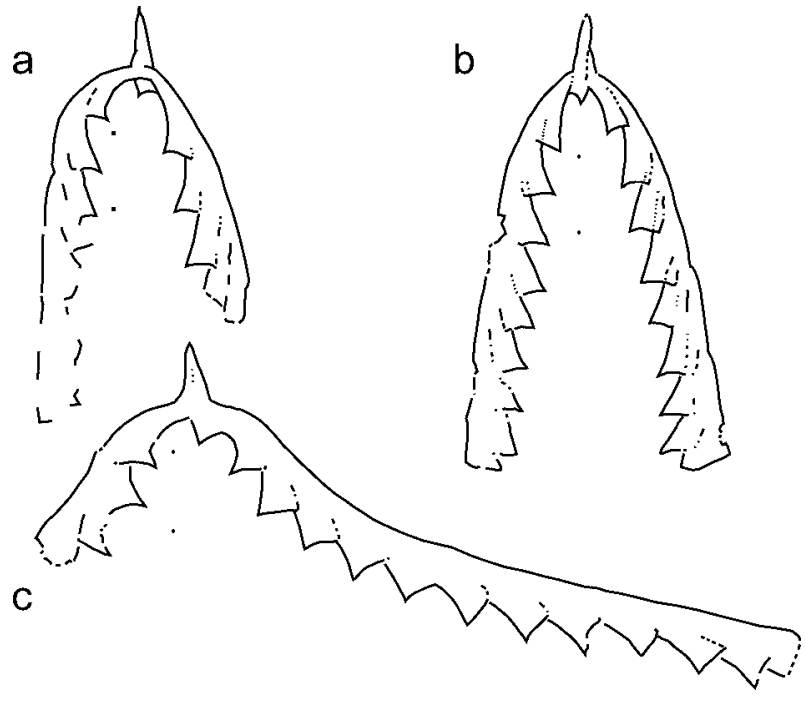

Figure 6. Graptolites from the Rumi Orkho Formation at Sella. (a) SE 01, Baltograptus minutus (Tullberg). (b) SE 02, B. minutus (Tullberg). (c) SE 03, Baltograptus sp. cf. B. deflexus (Elles \& Wood). Specimens at Geological Institute, Freie Universität Berlin, Germany. Magnification $\times 10$, indicated by two dots at a distance of $1 \mathrm{~mm}$ near proximal end of all specimens.

and Egenhoff, Maletz \& Erdtmann (2004) established a Baltograptus minutus Biozone in the mid-Arenig of southern Bolivia, correlatable with the Australasian Chewtonian. B. minutus is common in the Arenig of the Tøyen Shale Formation of Scandinavia (J. Maletz, unpub. Ph.D. thesis, Technische Univ. Berlin, 1992), where the faunal association indicates a restriction to the mid-Arenig (Chewtonian of the Australasian faunal succession), while Baltograptus sp. cf. B. deflexus appears in the upper part of the Pendeograptus fruticosus interval in Scandinavia, comparable to the Bendigonian 3-4 (see VandenBerg \& Cooper, 1992) and ranges into the $B$. minutus Biozone. The Rumi Orkho Formation thus corresponds to the Baltograptus minutus Biozone and is of mid-Arenig age.

\section{4.b. Cienega $\left(19^{\circ} 03^{\prime} 30^{\prime \prime} \mathrm{S}, 64^{\circ} 59^{\prime} 45^{\prime \prime} \mathrm{W}\right)$}

The locality is situated at the northern end of the village of Cienega, north of the main road between Sucre and Tarabuco. Cruziana ispp. occurs at several levels within an $1150 \mathrm{~m}$ thick interval of the Capinota and Anzaldo formations. Both units consist of intercalated sand-, silt- and mudstones separated by a fault originated during the Andean Orogeny (Cenozoic). The Anzaldo Formation displays a high sandstone-pelite ratio of about 2:1, whereas the underlying Capinota Formation is dominated by mudstones (sandstone-pelite ratio of about 1:3).

The majority of the specimens of Cruziana ispp. from this locality are rather poorly preserved, but some specimens show sufficient significant details for their taxonomic identification. As at Sella, the ichnofossils

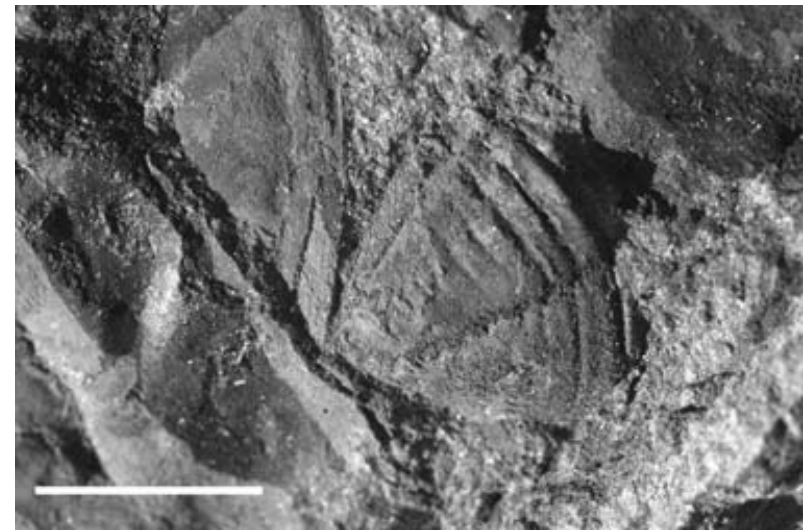

Figure 7. Pygidium of Neseuretus aff. sanlucasensis Přibyl \& Vaněk, 1980 from the lower portion of the succession exposed at Cienega. Scale bar equals $2 \mathrm{~cm}$. Specimen CC-01-02, stored at Geologisches Institut, Freie Universität Berlin, Germany.

occur as casts at the base of some centimetre-to decimetre-thick fine-grained sandstone beds.

The arthropod ichnofossil assemblage in both stratigraphic units is characterized by abundant $C$. furcifera and C. goldfussi (Figs 3e, 4d) accompanied by poorly preserved non-arthropod traces sometimes cutting through the Cruziana type traces (Palaeophycus isp. and Skolithos isp., see specimen in Fig. 3e). No true Cruziana rugosa was found at the Cienega locality.

\section{4.b.1. Biostratigraphic age of the Capinota Formation at Cienega}

The Capinota Formation at Cienega yielded a single relatively well-preserved steinkern of a pygidium of Neseuretus (Neseuretus aff. sanlucasensis Přibyl \& Vaněk, 1980) (Fig. 7). The genus Neseuretus ranges from the Arenig to the basal Ashgill (see Turvey, 2002). Neseuretus sanlucasensis is exclusively known from the Llanvirn of San Lucas (Hoekaspis zone) of Bolivia (Přibyl \& Vaněk, 1980). However, it is still a matter of debate if Neseuretus sanlucasensis can be included in the genus Neseuretus, or if it should be assigned to the genus Aristocalymene (Turvey, 2005). The reason is that the material figured in Prribyl \& Vaněk (1980) is incomplete and its cephalic morphology is therefore not completely understood (Turvey, 2005). But as the cladistic analysis undertaken in Turvey (2002) shows Neseuretus sanlucasensis to belong to the stem group of the later Neseuretinus-Vietnamia clade, it is more probable that the Bolivian specimen from the lower part of the Cienega succession indicates a late Arenig to Llanvirn age.

\section{4.b.2. Conodonts from the uppermost Anzaldo Formation at Cienega}

At the top of the Anzaldo Formation at the locality of Cienega, carbonate concretions contain conodont 


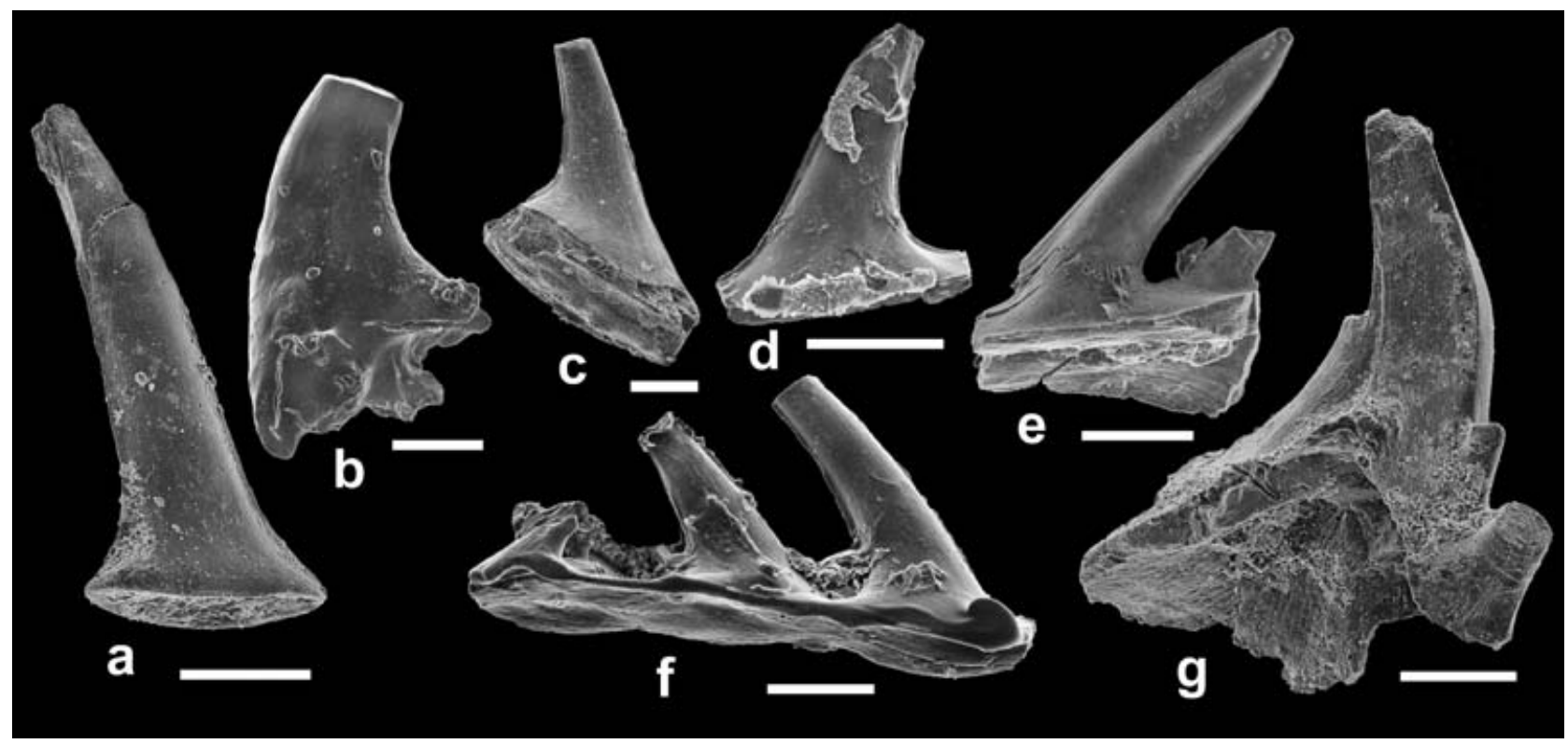

Figure 8. Conodont elements from the uppermost Anzaldo Formation from the Cienaga locality. Scale bars equal $100 \mu \mathrm{m}$. (a) Semiacontiodus sp., SMF 69990, lateral view, (b) Drepanoistodus? sp., SMF 69991, lateral view, (c-f) fragments of multidenticulate processes of Erismodus sp., (c) isolated denticle, SMF 69992, (d) isolated denticle, SMF 69993, (e) inner view of process fragment, SMF 69994, (f) inner view of process fragment, SMF 69995, (g) Erismodus cf. E. quadridactylus (Stauffer), Sb element postero-lateral view, SMF 69996.

faunas. The small assemblage includes fragmentary elements of Erismodus cf. E. quadridactylus (Stauffer) (Fig. 8g), isolated cusps and denticles of Erismodus elements (Fig. 8c-f), one fragment of Drepanoistodus? sp. (Fig. 8b) and some coniform elements of Semiacontiodus sp. (Fig. 8a). Unfortunately, no index taxa characteristic for a certain conodont zone were recovered. One special problem of Erismodus material is that the processes break easily at the boundaries between the different denticles (see, for example, the narrow connections between the denticles in the fragment in Fig. 8f). As a consequence, large cusp fragments occur together with isolated denticles in a way similar to material of Coryssognathus (Miller \& Aldridge, 1993) or in material of the giant conodont Promissum pulchrum described by Aldridge et al. (1995) from the Soom shale of South Africa. Bedding plane assemblages of Promissum in different stages of preservation well display that denticles sitting on basal tissue can easily be isolated (collections of R. A. Aldridge, University of Leicester). In a similar way, Coryssognathus elements fall apart and discrete cones in the collections often represent denticles broken from the multidenticulated processes but also discrete cones previously attached only to some basal tissue.

In hyaline material recovered from the Anzaldo Formation, fragments of cusps or large denticles without any preserved base can neither be attributed to Erismodus nor to Semiacontiodus. Only a few elements with complete, separate bases are placed into Semiacontiodus sp. (Fig. 8a) and large denticles sitting on some part of a process fragment (Fig. 8c-f) can (based on their association with Erismodus elements) tentatively be interpreted as fragments of Erismodus (Fig. 8c-f) but usually could not be distinguished from similar fragments of Polycaulodus or Chrirognathus duodactylus Branson \& Mehl 1933. In general, the apparatus structure of Erismodus is still under study and there are many problems in understanding the different species of this 'plastic' taxon. A modern diagnosis of Erismodus was given by Sweet (1982), who provides a detailed synonymy of Erismodus quadridactylus (Stauffer). In the Bromide Formation of Oklahoma, Erismodus arbuckelensis Bauer, Erismodus quadridactylus and Erismodus typus Branson \& Mehl 1933 occur and are distinguished by the character of their Sa elements (J. A. Bauer, unpub. Ph.D. thesis, Ohio State Univ. 1987; Bauer, 1994). In contrast to the smoothly rounded posterior side of the cusp in E. typus, E. quadridactylus is laterally and posteriorly costate like E. arbuckelensis but far less compressed (Bauer, 1994, p. 363). This is also a typical feature of the other elements in the E. quadridactylus apparatus (Sweet, 1982, pp. 1040-2, pl. 1, figs 25-30) and well recognizable in the figured $\mathrm{Sb}(?)$ element from the Anzaldo Formation. Because no diagnostic Sa element was recovered, the fragmentary material from the Anzaldo Formation is illustrated as Erismodus sp. (fragments illustrated on Fig. 8b-f) or E. cf. E. quadridactylus (in the case of a $\mathrm{Sb}$ element displaying a posterior-anteriorly compressed cusp with one posterior and sharp antero-lateral costaet costa, Fig. 8g). One badly preserved element which may represent a drepanodiform element of a Drepanoistodus is crushed basally and is illustrated as Drepanoistodus? sp. (Fig. 8b). 
The type of the limited hyaline fauna in the upper Anzaldo Formation is quite comparable to faunal assemblages described from the Santa Gertrudis Formation in northern Argentina. There, Sarmiento \& Rao (1987, pp. 90-2, pl. 1, figs 1-10, pl. 2, figs 110) described Erismodus quadridactylus for the first time from the clastic Gondwana succession of the Eastern Cordillera. From the coeval Capillas Formation in the Sierra de Zapla, an association of Erismodus, Erraticodon and Plectodina together with the agnathan fish Saccambaspis janvieri is mentioned by Albanesi \& Astini (2002) and Albanesi \& Moya (2002). More diverse faunas illustrated by Albanesi in Moya et al. (2003, p. 21, figs 12.1-12.17) from the Santa Gertrudis Formation in the Gallinato Creek section of the Mojoro Range in the Eastern Cordillera include Bryanthodina typicalis Stauffer 1935, Plectodina n. sp., Erismodus $\mathrm{cf}$. E. gratus (Moskalenko), Erismodus typus Branson \& Mehl 1933, Erismodus quadridactylus, Icriodella n. sp. A, Polycaulodus sp. and Semiacontiodus sp. This assemblage also included no useful zonal index taxa and was placed by Albanesi \& Ortega (2002, p. 149, fig. 1) into a 'non-nominated interval' ranging from the basal Eoplacognathus lindstoemi subzone of the Pygodus serra zone through the top of the Baltoniodus gerdae subzone of the Amorphognathus tvaerensis zone (Baltic zonation) or from the lower Chabagnathus sweeti through the top of the E. quadridactylus zone (North American Midcontinent zonation).

However, Erismodus quadridactylus (Stauffer, 1935) represents an important taxon ranging from the Mohawkian E. quadridactylus zone through the Plectodina tenuis zone in Sweet's North American chronostratigraphic scheme (Sweet, 1984, 1988) and therefore ranges up into slightly younger levels than proposed for the non-nominated interval (Fig. 9) by Albanesi \& Ortega (2002). The range of the taxon in North America correlates to upper fauna 7 through lower fauna 9 in the older literature (Sweet, Ethington \& Barnes, 1971), which is equivalent to the uppermost Baltoniodus gerdae subzone of the Amorphognathus tvaerensis zone through the uppermost Baltoniodus alobatus subzone of the A. tvaerensis zone (Sweet, 1984, 1988) and in terms of North American stages it includes approximately the upper part of the Turinian and the lower part of the Chatfieldian (Fig. 9). There is no detailed description of the conodont succession in the Mojotoro Range published yet, but the faunas of the Santa Gertrudis Formation and the Anzaldo Formation may be at least partly coeval. If the Erismodus faunas occur in approximately the same time interval in western Peri-Gondwana, a Turinian age (possibly E. quadridactylus zone) seems to be plausible.

\section{4.c. Tipa Jara near Aiquile $\left(18^{\circ} 12^{\prime} 00^{\prime \prime} \mathrm{S}, 65^{\circ} 17^{\prime} 30^{\prime \prime} \mathrm{W}\right)$}

The Cruziana ichnofossils in the surroundings of the village of Tipa Jara (SE of Cochabamba, central

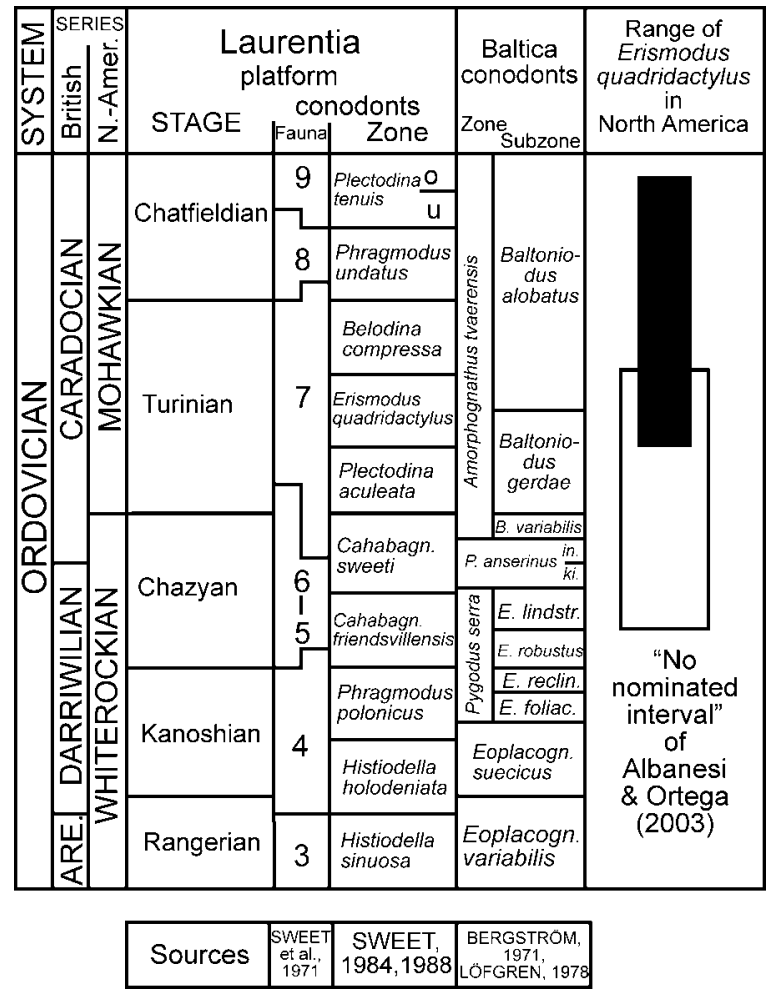

Figure 9. Stratigraphic chart showing the range of Erismodus quadridactylus (vertical black bar) according to Sweet $(1984,1988)$ and the 'non-nominated interval' (white box) of Albanesi \& Ortega (2002) for the faunas of the Santa Gertrudis Formation in the Mojotoro Range of northern Argentina.

Bolivia) occur in the lower to central part of an approximately $2400 \mathrm{~m}$ thick, largely tectonically undisturbed section (Fig. 10), exposing the Middle to Upper Ordovician Anzaldo Formation (M. Maldonado \& M. Montaño, unpub. Geobol report, 1967). The Tipa Jara succession consists of intercalated mud-, silt- and sandstones with sand- and siltstone-rich facies where the Cruziana specimens occur (C. Hildebrandt, unpub. Diploma thesis, Univ. Freiberg, 2003). The Cruziana traces are abundant in several decimetre-thick beds in three stratigraphic levels within overall Skolithosdominated facies often associated with Palaeophycus isp. The fossil material from this locality consists of two rather poorly preserved specimens of Cruziana $\mathrm{cf}$. furcifera (Fig. 4a, b), one specimen of $C$. goldfussi (Fig. 4e) and one excellently preserved specimen of C. rugosa (Fig. 3b).

No time-indicative fossils have been found in the entire succession at Tipa Jara so far. However, the conformably overlying San Benito Formation bears Upper Ordovician chitinozoans and lower Ashgill brachiopods (M. A. Perez Leyton, unpub. report, 1986; Suarez Soruco \& Benedetto, 1996). The ichnofossils occur about $850 \mathrm{~m}$ below the base of the San Benito Formation (Fig. 10), which is in the upper third of the Anzaldo Formation at this locality. The Llanvirn-Caradoc boundary is believed to be 


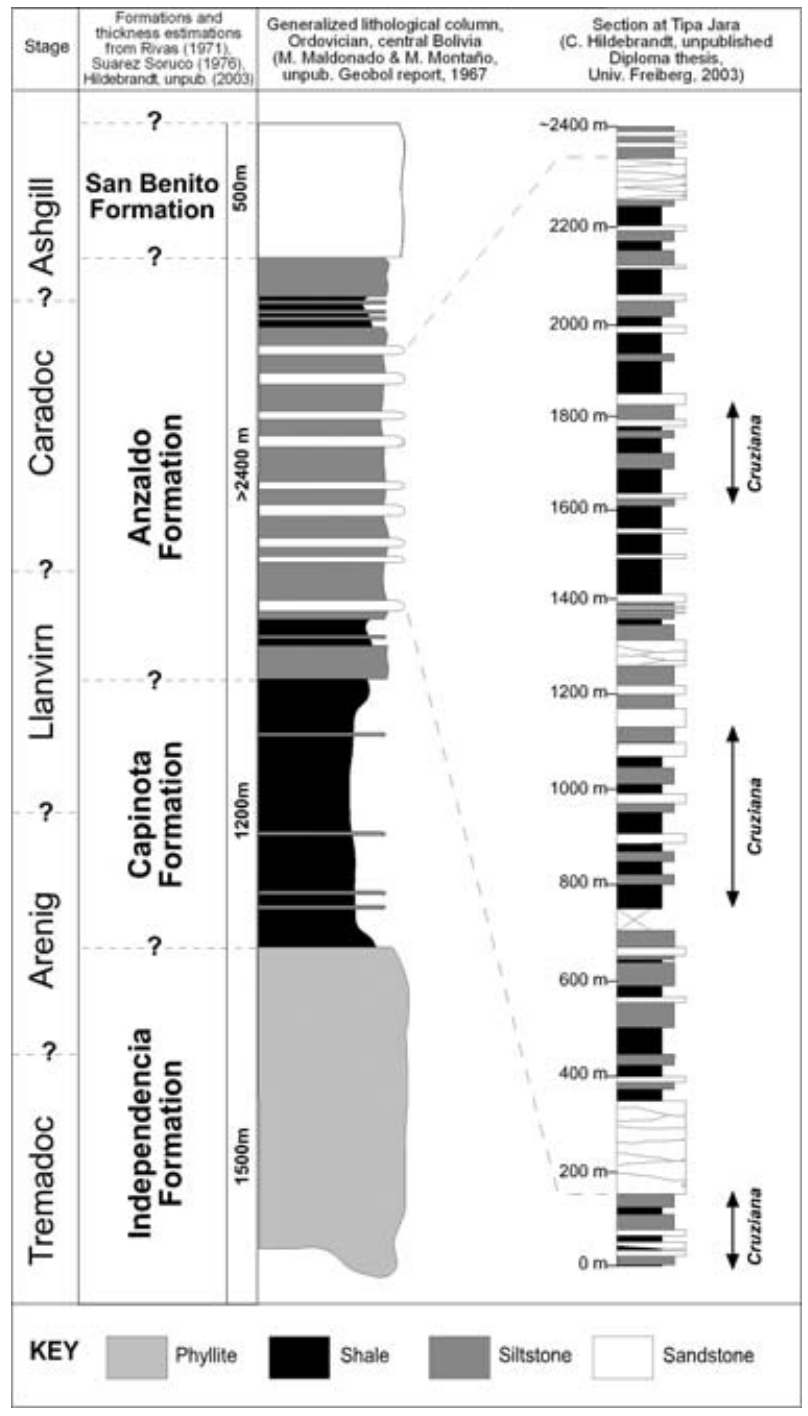

Figure 10. Overview section of the Ordovician succession in central Bolivia based on C. Hildebrandt (unpub. Diploma thesis, Univ. Freiberg, 2003), Rivas (1971) and Suarez Soruco $(1976,2000)$, and a detailed section from the Tipa Jara locality (C. Hildebrandt, unpub. Diploma thesis, Univ. Freiberg, 2003). The black arrows indicate stratigraphic portions where Cruziana occurs within the Anzaldo Formation. The last Cruziana was found in Tipa Jara about $850 \mathrm{~m}$ below the base of the Ashgill San Benito Formation.

located in the central part of the Anzaldo Formation (M. Maldonado \& M. Montaño, unpub. Geobol report, 1967). This argues for a Caradoc age of the Cruziana traces from Tipa Jara.

\section{4.d. Liriuni near Cochabamba $\left(17^{\circ} 17^{\prime} 06^{\prime \prime} \mathrm{S}, 66^{\circ} 17^{\prime} 40^{\prime \prime} \mathrm{W}\right)$}

The ichnofauna studied in 2001 in several outcrops near the village of Liriuni about $20 \mathrm{~km}$ north of Cochabamba (central Bolivia) is clearly dominated by C. goldfussi (Fig. 5a, b). These are frequently associated with abundant individuals of Palaeophycus isp. that often cut through the Cruziana. Branisa (1965, p. 78, pl. 7) figured a large slab from Liriuni with Cruziana furcifera, obviously accompanied by several individuals of $C$. goldfussi. D'Orbigny (1842) figured an excellently preserved specimen of $C$. rugosa from the Cochabamba region. Seilacher (1992) also has reported C. rugosa from the Cochabamba region. A rather poorly preserved but still significant specimen showing the typical bundle pattern on the surface from our locality at Liriuni is shown in Figure 3c. The trace fossils occur at numerous levels within an at least $500 \mathrm{~m}$ thick interval within the upper Anzaldo Formation that is dominated by decimetre-thick sandstones. Branisa (1965) referred to the Liriuni succession as belonging to the uppermost Caradoc. Recent acritarch and brachiopod data in the surroundings of Cochabamba (Gagnier et al. 1996) support a Llanvirn to Caradoc age for the Anzaldo Formation. As the Liriuni locality represents the uppermost part of the Anzaldo Formation only shortly below the contact with the lower Ashgill San Benito Formation (Suarez Soruco \& Benedetto, 1996), it is likely that the Cruziana faunas indeed have a late Caradoc age.

\section{4.e. Implications for $C$. rugosa biostratigraphy}

This study proves that in Bolivia, C. furcifera, C. goldfussi and C. rugosa occur in Arenig to Caradoc strata and therefore have a limited biostratigraphic relevance, indicating solely an Ordovician age when found in this part of Gondwana. These findings are in good agreement with earlier descriptions by Steinmann \& Hoek (1912), who figured a specimen of C. furcifera from Palca del Tunari near Cochabamba which probably has a middle to late Caradoc age (Gagnier, 1993; Gagnier et al. 1996). Only the taxon C. rouaulti seems to be restricted to Lower Ordovician successions in Bolivia. Its rareness even within these strata, however, inhibits a well-based statement on its true biostratigraphic range.

On a worldwide basis, the C. rugosa Group is not restricted exclusively to Lower Ordovician sediments, in contrast to Seilacher's (1992) statement, although it remains unclear what Seilacher (1970, 1992) defines as Lower Ordovician as he subdivides the Ordovician period only into Lower and Upper. C. rugosa, C. furcifera and C. goldfussi do occur in Middle Ordovician successions in the Armorican Massiv (Delgado, 1886; Lessertisseur, 1955; Seilacher, 1992) and in North Africa (Desio, 1940; Seilacher, 1992). C. rugosa, however, seems to be in fact restricted to a middle Tremadoc to Arenig interval throughout Gondwana. Although one study exists reporting C. rugosa from 'Lower Silurian strata' of the Yangtze platform (Yunnan) in southern China (Yin, 1932), recent graptolite findings by B.-D. Erdtmann (pers. comm. 2003) support an Early Ordovician rather than a Silurian age of these sediments. 


\section{Discussion}

The present study is not the first to question the reliability of the 'Cruziana rugosa Group' as a biostratigraphic indicator for the Lower Ordovician. Based on rather poor material judging from their figured specimens, Magwood \& Pemberton (1990) reported the occurrence of $C$. rugosa together with C. furcifera and C. goldfussi from the Lower Cambrian (Atdabanian) Gog Group of Alberta, Canada, and have generally questioned the value of Seilacher's biostratigraphic approach. The specimens figured in Magwood \& Pemberton (1990, p. 731, fig. 3A, B, C), however, are not really convincing: the ' $C$. goldfussi' in their figure $3 \mathrm{~B}$ shows no sign of any lateral ridges and looks very similar to the 'Cruziana rugosa' shown in figure $3 \mathrm{C}$ which again shows no transversal bundles and only very flat and diffuse declining margins (that is, not C. rugosa).

Seilacher (1994) presented better preserved fossil material from British Columbia, Canada, and has rejected the criticism made by Magwood \& Pemberton (1990). Based on the well-preserved specimens, Seilacher (1994) showed that the Gog Group specimens belong to a Cambrian Cruziana type (C. pectinata) having a distinct scratch pattern, and they therefore do not contradict his Cruziana stratigraphy. It should be taken into consideration that $C$. rugosa has not yet been reported from strata older than middle Tremadoc and therefore seems to have a biostratigraphic value in defining sediments younger than early Tremadoc in age.

The Ordovician successions in Bolivia where Cruziana ichnofossils occur are generally dominated by sandstones and are referred to as the 'Grès Armoricain Facies' by Seilacher (1992). This type of facies is widely distributed throughout Peri-Gondwana in the Lower Ordovician, but Upper Ordovician strata worldwide often exhibit finer-grained sediments. The Bolivian sections then correspond to a nearshore environment rarely preserved from the Late Ordovician time interval. Therefore, the exclusive occurrence of the C. rugosa Group in Lower Ordovician strata may be just an artefact of facies distribution in stratigraphy. Consequently, the occurrence of C. rugosa Group traces with the exception (?) of $C$. rouaulti probably does not represent a powerful biostratigraphic tool for subdividing otherwise non-fossiliferous Ordovician sandstones.

At least in South America (W. Gondwana), C. rugosa, C. furcifera and C. goldfussi therefore do not seem to be suitable as index fossils for a subdivision of the Ordovician system (sensu Seilacher, 1970, 1992, 1994; Baldwin, 1977; Crimes, 1968). Only the possibly very restricted biostratigraphic distribution of the rare taxon $C$. rouaulti (Fig. 5c) remains a matter of speculation. In fact, this ichnospecies is hitherto only known from the Lower Ordovician (Arenig) of North
Africa and Armorica and from the lower Arenig of Bolivia as demonstrated in the present study.

The palaeobiogeographic distribution of Cruzianatype arthropod traces may reflect the changing distribution patterns of a certain group of arthropod trace originators. Probably several large benthic trilobite taxa, highly adapted and specialized to shallowmarine siliciclastic environments, occurred successively in the Lower Palaeozoic on the passive continental margins of Gondwana.

\section{Conclusions}

(1) The taxonomic re-evaluation presented herein supports the subdivision of the C. rugosa Group into $C$. furcifera, $C$. goldfussi, $C$. rouaulti and C. rugosa as originally defined by Seilacher (1970). Based on our well-preserved specimens from Bolivia, we show that each of the four ichnospecies indeed displays sufficient characteristics, such as the presence or absence of lateral spine grooves, scratch patterns etc. to distinguish them unequivocally, even in the field. The statistical approach of Kolb \& Wolf (1979), negating a subdivision of the C. rugosa Group based on measurable criteria, therefore has to be considered invalid. This is because the V-angle of scratches as well as the amount of scratches per centimetre used in that study are not valuable parameters in differentiating ichnospecies of the Cruziana rugosa Group and should possibly not be considered a prime criterion for distinguishing Cruziana ichnogenera in general.

(2) In Bolivia, C. furcifera, C. goldfussi and C. rugosa occur in Lower to Upper Ordovician strata. Therefore, they cannot be regarded as a reliable biostratigraphic indicator for the Lower Ordovician at least for Bolivia and adjacent regions. Although up to now only known from Bolivia, it should be expected that in the sand-rich 'Grés Armoricain' facies these three ichnospecies may occur worldwide. The obvious diachronous appearance of $C$. furcifera, C. goldfussi and C. rugosa within and outside Gondwana casts doubts on the real value of a Cruziana-related biostratigraphy for a global subdivision and correlation within the Ordovician System. However, the Cruziana rugosa Group can be used to identify Ordovician strata in Bolivia.

Acknowledgements. The research and fieldwork in Bolivia was made possible by the financial support of the Deutsche Forschungsgemeinschaft DFG (SFB 267: Deformation Processes in the Andes, TPC3 and EG 141/1-1). We thank the German consul in Tarija (Bolivia), Carlos Methfessel, for important logistical support. Pepe Diaz (Tarija, Bolivia) kindly provided collection material. The authors are grateful to Mario Salamanca (Sucre, Bolivia) for his experienced guidance in the field and for his qualified support of our palaeontological and sedimentological fieldwork in 1998 and 2001. Bernd-D. Erdtmann (Berlin, Germany) helped to determine graptolite material from South China. Ramiro Suarez Soruco (Museo Alcide d'Orbigny, Cochabamba, Bolivia) supported our field seasons in the Cochabamba 
area in 1998 and 2001. Simon Braddy (University of Bristol, UK) kindly commented on an earlier version of the present manuscript and corrected the English. We thank $\mathrm{S}$. Jensen and R. Goldring for reviews that significantly improved the manuscript. This paper is a contribution to the IGCP project no. 503 'Ordovician Palaeogeography and Palaeoclimate'.

\section{References}

AlbANESI, G. L. \& Astini, R. A. 2002. Faunas de conodontes y Sacabambaspis janvieri (Vertebrata) en el Ordovícico Medio de la Cordillera Oriental Argentina. 8th Congreso Argentino de Paleontología y Bioestratigrafia, Resumenes 1, 17.

AlBANESI, G. L. \& MoYA, M. C. 2002. Biostratigrafía de la Formación Sepulturas (Ordovícico), en el flanco occidental de da Cordillera Oriental Argentina. 8th Congreso Argentino de Paleontología y Bioestratigrafia, Resumenes 1, 17.

Albanesi, G. L. \& Ortega, G. 2002. Advances on conodont-graptolite biostratigraphy of the Ordovician System of Argentina. In Aspects of the Ordovician System of Argentina (ed. F. G. Aceñolaza), pp. 14365. Serie Correlación Geológica no. 16. Tucumán: INSUGEO.

Aldridge, R. J., Purnell, M. A., Gabbott, S. E. \& THERON, J. N. 1995. The apparatus architecture and function of Promissum pulchrum Kovas-Endrony (Conodonta, Upper Ordovician) and the prioniodontid plan. Philosophical Transactions of the Royal Society, London B347, 275-91.

BALDWIN, C. T. 1977. The stratigraphy and facies association of trace fossils in the Cambrian and Ordovician rocks of north western Spain. In Trace Fossils 2 (eds T. P. Crimes and J. C. Harper), pp. 9-40. Geological Journal Special Issue no. 9. Liverpool: Seel House Press.

BAUER, J. A. 1994. Conodonts from the Bromide Formation (Middle Ordovician), south-central Oklahoma. Journal of Paleontology 68, 358-76.

BergströM, S. M. 1971. Conodont Biostratigraphy of the Middle and Upper Ordovician of Europe and Eastern North America. In Symposium on Conodont Biostratigraphy (eds W. C. Sweet and S. M. Bergström), pp. 83-161. Geological Society of America, Memoir no. 127 . Boulder.

BergströM, J. 1976. Lower Palaeozoic trace fossils from eastern Newfoundland. Canadian Journal of Earth Sciences 13, 1613-33.

Birkenmajer, K. \& Bruton, D. L. 1971. Some Trilobite Resting and Crawling Traces. Lethaia 4, 303-19.

BranisA, L. 1965. Los Fósiles Guias de Bolivia. I. Paleozoico. Servicio Geologico de Bolivia Boletin 6, 1-282.

Branson, E. B. \& Mehl, M. G. 1933. Conodont Studies. Missouri University Studies 8, 1-349.

CRIMES, T. P. 1968. Cruziana: a stratigraphically useful trace fossil. Geological Magazine 105, 360-64.

CRIMES, T. P. 1969. Trace Fossils from the CambroOrdovician Rocks of North Wales and their Stratigraphic Significance. Geological Journal 6, 333-8.

CRIMES, T. P. 1970. Trilobite tracks and other trace fossils from the Upper Cambrian of North Wales. Geological Journal 7, 47-68.
Crimes, T. P. \& Marcos, A. 1976. Trilobite traces and the age of the lowest part of the Ordovician reference section for NW Spain. Geological Magazine 113, 349-56.

Delgado, J. F. N. 1886. Etude sur les Bilobites et autres Fossiles des Quartzites de la Base du Systeme Silurique du Portugal. Lisbon: Imprimerie de l'Academie Royale des Sciences Lisbonne, $113 \mathrm{pp}$.

Desio, A. 1940. Vestigia problematiche della Libia. Annali del Museo Libico di Storia Naturale, Governo della Libia, Tripoli d'Africa 2, 47-92.

D'Orbigny, A. C. V. 1839. Voyage dans l'Amérique Méridionale. Tome 8 (Atlas), Pitois-Levrault (Paris) et Levrault (Strasbourg), no pagination.

D'Orbigny, A. C. V. 1842. Voyage dans l'Amérique Méridionale, Tome Troisième, 4. Partie, Paléontologie. Paris and Strasbourg: Pitois-Levrault et Levrault, 188 pp.

DurAND, J. 1985. Le Gres Armoricain. Sédimentologie Traces fossiles. Milieux de dépôt. Rennes: Memoires et Documents du Centre Armoricain d'Etude Structurale des Socles, $119 \mathrm{pp}$.

EgENHOFF, S. O. 2000. Sedimentologie und Beckenentwicklung im Ordovizium in Südbolivien. Berliner Geowissenschaftliche Abhandlungen A207, 1-173.

Egenhoff, S. O., Maletz, J. \& ERDTMAnN, B.-D. 2004. Lower Ordovician graptolite biozonation and lithofacies of southern Bolivia: relevance for palaeogeographic interpretations. Geological Magazine 141, 287 99.

ERdtManN, B.-D., Kley, J., Müller, J. \& JaCobshagen, V. 1995. Ordovician basin dynamics and new graptolite data from the Tarija region, Eastern Cordillera, south Bolivia. In Ordovician Odyssey: Short papers for the seventh International Symposium on the Ordovician System (eds J. D. Cooper, M. L. Droser and S. C. Finney), pp. 69-73. The Pacific Section Society for Sedimentary Geology (SEPM), Book 77.

Frey, R. W. \& PEMBERTON, S. G. 1984. Trace fossils facies models. In Facies Models (eds R. G. Walker and N. P. James), pp. 189-207. Geoscience Canada Reprint Series. St. John's: Geological Association of Canada Publications.

GAGNIER, P.-Y. 1993. Sacabambaspis janvieri, Vértebré Ordovicien de Bolivie: I: Analyse Morphologique. Annales de Paléontologie (Vert.-Invert.) 79, 19-51.

Gagnier, P.-Y., Bliek, A., Emig, C. C., Sempere, T., VACHARD, D. \& VAnguestaine, M. 1996. New paleontological and geological data on the Ordovician and Silurian of Bolivia. Journal of South American Earth Sciences 9, 329-47.

GohrBANDT, K. H. A. 1992. Paleozoic paleogeographical and depositional developments on the central protoPacific margin of Gondwana: their importance to hydrocarbon accumulation. Journal of South American Earth Sciences 6, 267-87.

KolB, S. \& WOLF, R. 1979. Distribution of Cruziana in the Lower Ordovician sequence of Celtiberia (NE Spain) with a revision of the Cruziana rugosa-group. Neues Jahrbuch für Geologie und Paläontologie, Monatsheft 8, 457-74.

Lebesconte, M. P. 1883. Les Cruziana et Rysophycus connus sus le nom général de bilobites sont-ils des végétaux ou des traces d'animaux. In Oevres posthumes de Marie Rouault (ed. M. P. Lebesconte), pp. 61-73. Rennes.

LESSERTISSEUR, J. 1955. Traces Fossiles d'Activité Animale leur Signification Palaéobiologique. Mémoirs de la 
Société Géologique de France, Nouvelle Série 74, 1148.

LÖFGREN, A. 1978. Arenigian and Llanvirnian conodonts from Jämtland, northern Sweden. Fossils and Strata 13, $1-129$.

Magwood, J. P. A. \& Pemberton, G. S. 1990. Stratigraphic significance of Cruziana: New data concerning the Cambrian-Ordovician ichno-stratigraphic paradigm. Geology 18, 729-32.

MALETZ, J. \& EGENHOFF, S. O. 2001. Late Tremadoc to early Arenig graptolite faunas of southern Bolivia and their implications for a worldwide biozonation. Lethaia 34, 47-62.

Maletz, J. \& Egenhoff, S. O. 2003. Lower to Middle Ordovician graptolite biostratigraphy of southern Bolivia. Revista Tecnica de YPFB 21, 103-15.

MALetZ, J., KleY, J. \& ReInHARDT, M. 1995. New data on the Palaeontology and Biostratigraphy of the Ordovician in Southern Bolivia. Newsletters on Stratigraphy 32, $163-73$.

MÁngano, M. G. \& Buatois, L. A. 2003. Trace fossils. In Ordovician fossils of Argentina (ed. J. L. Benedetto), pp. 507-34. Universidad Nacional de Córdoba.

Mángano, M. G., Buatois, L. A. \& Aceñolaza, G. F. 1996. Trace fossils and sedimentary facies from a Late Cambrian-Early Ordovician tide-dominated shelf (Santa Rosita Formantion, northwest Argentina): Implications for ichnofacies models of shallow marine successions. Ichnos 5, 53-88.

Mángano, M. G., Buatois, L. A. \& Moya, M. C. 2001. Trazas fósiles de trilobites de la Formación Mojotoro (Ordovícico Inferior-Medio de Salta, Argentina): Implicaciónes paleoecológicas, paleobiológicas y bioestratigráficas. Revista Española de Paleontología 16, 9-28.

Miller, C. G. \& AldRIDGE, R. J. 1993. The taxonomy and apparatus structure of the Silurian distomodontid conodont Coryssognathus Link Druce, 1972. Journal of Micropalaeontology 12, 241-55.

Moya, M. C., Monteros, J. A., Malanca, S. \& AlBANESI, G. L. 2003. The Mojotoro Range, Eastern Cordillera, Salta Province. In Ordovician and Silurian of the Cordillera Oriental and Sierras Subandinas, NW Argentina (eds M. C. Moya, G. Ortega, J. A. Monteros, S. Malanca, G. L. Albanesi, L. A. Buatois and F. J. Zeballo), pp. 17-22. Field Trip Guide 9th ISOS, 7th IGC \& FMSSS Miscellanea no. 11. Tucumán: INSUGEO.

Pemberton, S. G., Frey, R. W., Ranger, M. J. \& MACEACHERN, J. A. 1992. The conceptual framework of ichnology. In Application of ichnology to petroleum exploration, a core workshop (ed. S. G. Pemberton), pp. 1-32. Society for Sedimentary Geology, Core Workshop no. 17. Tulsa: SEPM.

PÉNEAU, J. 1946. Etude sur l'Ordovicien Inférieur (Arenigien $=$ Grès Armoricain) et sa faune (spécialement en Anjou). Bulletin Société Etudes Scienifiques d'Angers 74-76 (1944-46), 37-106.

Pickerill, R. K., Romano, M. \& Meléndez, B. 1984. Arenig trace fossils from the Salamanca area, western Spain. Geological Journal 19, 249-69.

PŘIBYL, A. \& VANĚK, J. 1980. Ordovician trilobites of Bolivia. Rozpravy Československé Akademie Věd Řada Matematických a Přirodnich Věd Academia Praha, Sešit $290,1-90$.

RIVAS, S. 1971. Algunas novedades sobre la estratigrafía del Ordovícico. Servicio Geológico de Bolivia Boletin 15, 5-12.
Rivas, S., FernandeZ, A. \& Alvaro, R. 1969. Estratigrafía de los sistemas Ordovícico-Cambrico y Precambrico en Tarija, sud de Bolivia. Sociedad Geológica Boliviana Boletín 9, 27-50.

RouAULT, M. M. 1850. Note préliminaire sur une nouvelle formation découverte dans le terrain silurien inférieur de la Brètagne. Bulletin de la Société Géologique de France, Deuxiéme Sérié 7, 724-44.

SALTER, J. W. 1853. On the lowest fossiliferous beds of north Wales. British Association for the Advancement of Science, Report for 1852, 286-302.

SARMIENTO, G. N. \& RAO, R. I. 1987. Erismodus quadridactylus (Conodonta) en la Formación Santa Gertrudis (Ordovícico), Provincia de Salta, Argentina. IV Congreso Latinoamericano de Paleontología 1, 89-95.

SEILACHER, A. 1960. Lebensspuren als Leitfossilien. Geologische Rundschau 49, 41-50.

SEILACHER, A. 1970. Cruziana stratigraphy of 'nonfossiliferous' Palaeozoic sandstones. In Trace Fossils (eds T. P. Crimes and J. C. Harper), pp. 447-76. Geological Journal Special Issue no. 3. Liverpool: Seel House Press.

SeILACHER, A. 1990. Paleozoic trace fossils. In The Geology of Egypt (ed. R. Sad), pp. 649-70. Rotterdam: Balkema.

SeILACHER, A. 1992. An Updated Cruziana Stratigraphy of Gondwanan Palaeozoic Sandstones. In The Geology of Libya, volume IV (eds M. J. Salem, O. S. Hammuda and B. A. Eliagoubi), pp. 1565-81. Amsterdam: Elsevier.

SEILACHER, A. 1994. How valid is Cruziana Stratigraphy? Geologische Rundschau 83, 752-8.

SEILACHER, A. \& CRIMES, T. P. 1969. "European" Species of Trilobite Burrows in Eastern Newfoundland. Memoir of the American Association of Petroleum Geologists 12, $145-8$.

SEMPERE, T. 1995. Phanerozoic evolution of Bolivia and adjacent regions. Memoir of the American Association of Petroleum Geologists 62, 207-30.

STAUFFer, C. R. 1935. Conodonts of the Glenwood beds. Geological Society of America Bulletin 46, 125-68.

SteinmanN, G. \& HoEK, H. 1912. Das Silur und Cambrium des Hochlandes von Bolivia und ihre Fauna. Neues Jahrbuch für Mineralogie, Geologie und Paläontologie 34, 176-252.

SUAREZ SORUCO, R. 1976. El sistema Ordovícico en Bolivia. Actas I. Congreso Argentino de Palaeontología $y$ Bioestratigrafia 1, 133-48.

SuArez Soruco, R. 2000. Compendio de Geología de Bolivia. Revista Técnica de YPFB 18, 1-210.

SuAREZ SoruCO, R. \& BenEDETTO, J. L. 1996. Primero datos sobre la fauna de braquiópodos de la formación San Benito en la Cordillera de Tunari, Cochabamba, Bolivia. Memorias del XII Congreso Geológico Boliviano 1, 211-16.

SwEET, W. C. 1982. Conodonts from the Winnipeg Formation (Middle Ordovician) of the Northern Black Hills, South Dakota. Journal of Paleontology 56, 1029-49.

SwEET, W. C. 1984. Graphic correlation of upper Middle and Upper Ordovician rocks, North American Midcontinent Province, USA. In Aspects of the Ordovician System (ed. D. L. Bruton), pp. 23-35. Palaeontological Contributions from the University of Oslo no. 295. Oslo: Universitetsførlaget.

SwEET, W. C. 1988. The Conodonta: Morphology, taxonomy, paleoecology and evolutionary history of a long-extinct animal phylum. Oxford Monographs on Geology and Geophysics no. 10. Oxford: Oxford University Press, 169 pp. 
Sweet, W. C., Ethington, R. L. \& Barnes, C. R. 1971. North American Middle and Upper Ordovician conodont faunas. In Symposium on conodont biostratigraphy (eds W. C. Sweet and S. M. Bergström), pp. 163-9. Geological Society of America, Memoir no. 127. Boulder.

TurveY, S. T. 2002. Phylogeny of the Reedocalymeniae (Trilobita): implications for Early Ordovician biogeography of Gondwana. In Palaeobiogeography and biodiversity change: the Ordovician and MesozoicCenozoic radiations (eds J. A. Crame and A. W. Owen), pp. 53-68. Geological Society of London, Special Publication no. 194.
TuRVEY, S. T. 2005. Reedocalymenine trilobites from the Ordovician of central and eastern Asia, and a review of species assigned to Neseuretus. Palaeontology 48, 54975.

VAndenBerg, A. H. M. \& CoOper, R. A. 1992. The Ordovician graptolite sequence of Australasia. Alcheringa 16, 33-85.

YounG, F. G. 1972. Early Cambrian and Older Trace Fossils from the Southern Cordillera of Canada. Canadian Journal of Earth Sciences 9, 1-17.

YIN TSAN-HsUN. 1932. On the Occurrence of Cruziana (Bilobites) in Yunnan and Szechuan. Bulletin of the Geological Society of China 12, 75-80. 